DOI https://doi.org/10.18551/rjoas.2020-10.07

\title{
MONEY ETHICS MODERATION, ORGANIZATIONAL COMMITMENT AND ORGANIZATION ETHICAL CULTURE ON THE EFFECT OF BUDGET PARTICIPATION ON BUDGETARY SLACK
}

\author{
Jati I Ketut, Widhiyani Ni Luh Sari \\ Faculty of Economics and Business, University of Udayana, Bali, Indonesia \\ *E-mail: jatiketut@yahoo.com
}

\begin{abstract}
Budgetary slack is suspected to have occurred at the Office of Information and Communication Technology Management and State Property (KPTIK and BMN work unit), the Ministry of Finance of the Republic of Indonesia, which is possibly caused by dysfunctional behavior in budget participation. Raudhiah et al. 2013 emphasized that budgetary slack is used to make budget targets easier to achieve by manipulating the budget. However, the empirical research that has been conducted by several researchers shows inconsistent results which indicate a moderating role for contingency factors. The purpose of this study is to confirm the effect of budget participation on budgetary slack. The study population was a registered tax consultant and worked in the KPTIK and BMN (Ministry of Finance) work unit. The sampling technique was purposive sampling. Furthermore, data was collected through primary data sources using a questionnaire from previous researchers which was modified and fulfilled the validity and reliability test requirements of the instrument. Then, the data collected were tabulated and several tests and analyzes were carried out, namely: 1) classical assumption test to ensure fulfillment of the requirements for Best Linear Unbiased Estimator (BLUE), 2) Descriptive Static Analysis, 3) model feasibility test (F test), 4) analysis of the coefficient of determination (Adj. $\mathrm{R} 2$ ), and 5) test the research hypothesis (t-test). The MRA test results found that budgetary participation has a positive and significant effect on budgetary slack. Money ethics does not significantly increase the positive effect of budget participation on budgetary slack. Organizational commitment weakens the positive effect of budget participation on budgetary slack significantly. The ethical culture of the organization weakens significantly the positive influence of budget participation on budgetary slack.
\end{abstract}

\section{KEY WORDS}

Budget slack, budget participation, money ethics, organizational commitment, ethical culture.

Budgetary slack is strongly suspected to have occurred in the work unit (satker) of the Office for the Management of Information and Communication Technology and State Property (KPTIK and BMN) of the Ministry of Finance of the Republic of Indonesia which is indicated by spending realization in 3 (three) years (2015-2017) on average - an average of $81.45 \%$ of the spending plan (details, see attachment 1). Expenditure realization that is lower than the recurring expenditure budget is not a good performance because it is an indication of the practice of budgetary slack (Dunk, 1993).

One of the factors that should be suspected of triggering budgetary slack is budget participation. Budget participation in the budgeting process has a good purpose, but in the participation process, it often links budgeting behavior which is contrary to the vision of the Minister of Finance Regulation Number 93 / PMK.02 / 2017. Strived for budget participation in the budgeting process so that the budget is realistic because it involves those who realize the budget. However, budget participation is often counter-productive if the budgeting process is not sufficiently controlled. Chin-Chun et al (2013) stated that budgetary slack will increase when sub-ordination managers participate in budgeting. Furthermore, Raudhiah et al. 2013 emphasized that budgetary slack is used to make budget targets easier to achieve by manipulating the budget. 
Research related to the effect of budget participation on budgetary slack has been carried out by several researchers who found different results. Research conducted by Falikhatun (2008), Andriyani and Hidayati (2010), Sandrya (2013), Mahadewi (2013), and Triadhi (2013) found that higher budget participation leads to higher budgetary slack. Meanwhile, research by Desmiyati (2009) and Supanto (2010) found that budget participation reduces budgetary slack.

The results of this different study are interesting to explore because it is reasonable to suspect that other factors play a role in the effect of budget participation on budgetary slack (Latuheru, 2005). The difference in the results of these studies, according to Govindarajan (1986), can be resolved through a contingency approach, namely by including other variables that might moderate (strengthen or weaken) the effect of budget participation on budgetary slack. Several contingency factors that are relevant and urgent to reveal their moderating role are the variable money ethics, organizational commitment, and organizational ethical culture.

A person with high money ethics usually has a high love for money, will place great importance on money, and will be less ethical than people with low money ethics (Tang, 2002). They will behave dysfunctionally when allowed to participate in the budgeting process. Furthermore, individuals with high organizational commitment will have a strong belief and support for the values and goals that the organization wants to achieve (Mowday et al., 1979). Employees with high organizational commitment will apply the budget for organizational purposes, but on the contrary, if the commitment is low, of course, they will use the budget for their own needs and interests. Furthermore, the ethical culture of the organization is the employee's perception of ethical actions and the importance of ethics in the company, and the extent to which rewards or sanctions for immoral actions are carried out consequently and fairly (Hunt et al., 1989). A good organizational ethical culture will be able to prevent the negative impact of budget participation, and the opposite can occur if the ethical culture of the organization is not good. What is the real role of the three contingency factors, whether they can moderate the effect of budget participation on budgetary slack or vice versa, is an interesting thing that will be tried to reveal through this research.

This research tries to reveal the role of three aspects of behavior at once (money ethics, organizational commitment, and organizational ethical culture) as a contingency factor in the practice of participatory budgeting in one of the work units of the Ministry of Finance of the Republic of Indonesia. Of course, this research is an effort to help the KPTIK and BMNMinistry of Finance work units to confirm the alleged dysfunctional behavior of budget participation and at the same time provide relevant suggestions for continuous improvement.

\section{LITERATURE REVIEW}

Agency Theory and Budgetary Slack. Agency theory in the budgeting process is related to the budgetary slack phenomenon, which is often referred to as padding the budget (Hilton, 1994). Based on agency theory, subordinates are involved in budgeting and making budget targets to be easier to achieve, namely by setting higher costs but lower set budget targets (Maskun, 2008).

Budgetary slack is a tendency carried out by agent managers when allowed to participate in budgeting, to underestimate revenue, or overestimate expenditure. This is done because the budget is used as a basis for appraising the performance of the agent manager so that to facilitate the level of achievement they will carry out a budgetary slack. Based on observations of various previous studies, it is concluded that the variables that influence can be classified into three types, namely environmental, organizational, and individual factors.

Young (1985) states that budgetary slack is an act of subordinates who play down their productive capabilities when they are allowed to determine their performance standards. Ikhsan (2011) defines budgetary slack as the difference between the resources needed and the resources budgeted for completing tasks. Meanwhile, Anthony and Govindarajan (2011) state that budgetary slack is the difference between the amount submitted by the subordinates and the best estimate from the organization. 
Budgeting at the KPTIK and BMN scope of the Ministry of Finance starts from budgeting by existing sub-sections or sections. In this process, each party submits a budget according to the work plan that has been made. The budget set is a component of the spending unit budget which will be jointly realized in the fiscal year. The information held by each section is used to prepare the budget for the satker authorized by the Head Office. The Head of the Satker as the Budget User Proxy is in charge of compiling and being responsible for the work plan of the spending unit budget with the assistance of his subordinates, both in the preparation and implementation of the budget for the satker he leads.

Theory of Planned Behavior. The Theory of Planned Behavior (TPB) is a further development of the Theory of Reasoned Action (TRA). Ajzen (2005) adds a construct that does not exist in the Theory of Reasoned Action, namely perceived behavioral control. This construct is added to understand the limitations that individuals have to carry out certain behaviors. TPB describes specific behavior in individuals. This theory predicts and explains human behavior in certain contexts. This study uses the TPB approach because, in the budget preparation process, budget participants have different behaviors in preparing budgets, both related to money ethics, organizational commitment, and organizational ethical culture.

Budget, Budgeting, Purpose, and Benefits. Budget is a very important element in the planning, coordination, and control of the company, which contains plans for future activities and indicates activities to achieve company goals (Hansen and Mowen, 1997; Nouri, 1996). Budgeting in public sector organizations is a political process, where the budget is an instrument of accountability for the management of public funds and the implementation of programs financed with public money (Mardiasmo, 2002).

Budgeting is the creation of an activity plan that is expressed in financial terms. Budgeting plays an important role in planning, controlling, and decision-making, as well as for improving coordination and communication between interested parties / involved in the implementation of later activities (Mardiasmo, 2007). Budgeting is the most important part of government financial management and can be explained from various perspectives, such as politics, economics, finance, and accounting (Abdullah, 2012).

The objectives of budgeting according to Anthony and Govindarajan (1998) are: improving strategic plans, coordinating the activities of various parts of the organization, directing responsibility to managers, providing feedback to managers on their performance, as an agreement or commitment which is the basis for evaluating real manager performance.

The benefits of budgeting according to Yusfaningrum et al (2005) are (1) The budget is the result of the planning process and the budget means that it represents a negotiation agreement between dominant participation in an organization regarding the objectives of future activities (2) The budget is a description of the priority of resource allocation because it can act as a blueprint for company activities (3) As a means of communication between divisions, where the budget can greatly help carry out internal communication between divisions within the organization and top management.

Hypotheses. Budget participation is a process in an organization that involves individuals, namely managers in budgeting to determine budget objectives and budget targets (Brownell, 1982). The budgeting process can be done using top-down, bottom-up, and participatory methods. Budgeting is one means of participating in decision making. The budget preparation process is part of a series of budget processes prepared by the director (principal) and manager (agent). Budget participation is expected to be able to accommodate the budget required by the unit and the programmed plans (Coryanata, 2006; Purwantini and Suratno, 2007).

Several researchers have conducted research related to the effect of budget participation on budgetary slack. Research conducted by Lowe and Shaw (1968), Young (1985), Lukka (1988), Falikhatun (2008), Andriyani and Hidayati (2010), Sandrya (2013), Mahadewi (2013), Triadhi (2013), and Maharani (2015), found that high budget participation can lead to budgetary slack. 
Based on the description above, it can be said that the higher the budget participation, the greater the possibility of budgetary slack. Thus, based on the theory, concept, empirical research, and logical thinking described above, the following hypothesis can be developed:

$H_{1}$ : Budget participation has a significant positive effect on budgetary slack.

Money is one aspect that is very important in everyday life and is often used to measure success. Rubenstein (1981) and Elias \& Faraq (2010) argue that in the United States a person's success is measured by money and income, whereas in a study by Mitchell \& Mickel (1999) money is very important to individual personality and is an attitude variable. Basri (2013) states that money ethics is a person's view of money. Someone who has high money ethics, also known as the love of money, will place higher importance on money and ethically less sensitive than people who have low money ethics (Tang, 2002).

Several researchers such as Tang \& Chiu (2003), Vitell et al (2006), Vitell, et al (2007) found that high love of money or money ethics is the root of all crimes. Tang \& Chiu (2003) theorize that the love of money is closely related to the concept of greed. They revealed that Hong Kong employees with a high level of love for money were less satisfying at work than their peers. Furthermore, Chen and Tang (2006) assert that excessive love for money can lead to unethical behavior. Tang \& Chiu (2003) also found a direct relationship between money ethics and unethical behavior among professional employees in Hong Kong.

According to the preceding narrative, it can be seen that money ethics or a high love for money is closely related to greed, encourages unethical behavior, and even unsatisfactory performance, which when linked to budgeting has the potential to increase the positive influence of budget participation on budgetary slack. Based on the concepts, framework empirical research, and logical thinking described above, the following research hypotheses can be developed:

$\mathrm{H}_{2}$ : Money ethics significantly increases the positive effect of budget participation on budgetary slack.

Luthans (2006) defines organizational commitment as (1) a strong desire to become a member of a group, (2) a high willingness to work for the organization, (3) a certain belief and acceptance of the values and goals of the organization. . According to Jewell and Siegall (1998), work commitment can be defined as the degree of an individual's relationship with his or her work in a particular organization. Organizational commitment is a strong belief and support for the values and goals the organization wants to achieve (Mowday et al., 1979). Employees with high commitment will apply the budget for organizational purposes, but if someone with low commitment will certainly use the budget for their needs and interests. In the government context, officials who feel that their budget targets are clear will be more responsible if they are supported by high levels of commitment by officials to government organizations. This will encourage the apparatus to prepare a budget according to the goals the organization wants to achieve. Managers who have a high level of organizational commitment will have a positive outlook and try to do their best for the benefit of the organization (Porter et al., 1973).

The results of Keller's (1997) study reveal that high organizational commitment will tend to reduce budgetary slack and significantly affect performance. Then, Wardani's research (2016) found that employees who have high organizational commitment always try to be able to complete their tasks so that organizational goals will be easily achieved.

Based on the explanation above, it can be seen that commitment has a negative effect on budgetary slack. This happens because sub-ordination managers or subordinates with high organizational commitment will provide strong support for the values and goals to be achieved by the organization and will control their desire to carry out budgetary slack, so it is reasonable to predict that it will be able to reduce the positive influence of budget participation on slack. budget. So, based on the concepts, empirical research, and logical frameworks narrated above, the following research hypotheses can be developed:

$\mathrm{H}_{3}$ : Organizational commitment significantly weakens the positive effect of budget participation on budgetary slack.

Hurtet al, (1986) explained that organizational ethical culture is a broad view of employees' perceptions of the leader's ethical actions on the importance of ethics in the 
company and provides rewards or sanctions for immoral actions. Organizational ethical culture is an important component in improving employee performance because it provides views of good behavior that must be implemented (Trisnaningsih, 2007). Marwansyah (2012: 185) explains that organizational ethical culture is a system of values, norms, and beliefs shared by each member of the organization which then influences how to work and behave among members of the organization to create good and ethical behavior and avoid action. which can harm the organization.

Based on the narrative above, it can be seen that the ethical culture of an organization is a system of values, norms, and beliefs shared by each member of the organization, which underlies how to work and behave well so as not to harm the organization. The ethical culture of the organization then underlies employees' perceptions of ethical actions. These values certainly have a potential role in reducing budgetary slack because they can control negative behavior that is contrary to the purpose of implementing budget participation. The results of empirical research, and the logical framework above, can be developed as follows:

$\mathrm{H}_{4}$ : The ethical culture of the organization significantly weakens the positive influence of budget participation on budgetary slack.

\section{METHODS OF RESEARCH}

This study wants to confirm the alleged positive effect of budget participation on budgetary slack. Specifically, this research first wants to confirm whether money ethics reinforce the positive effect of budget participation on budgetary slack; second, to reveal whether organizational commitment and organizational ethical culture can weaken the positive influence of budget participation on budgetary slack.

The population in this study were employees, both structural and implementing officials at the KPTIK and BMN scope of the Ministry of Finance, based on the Minister of Finance Regulation No. Budget. The research sample was determined by purposive sampling method with criteria, among others, (1) structural and executing officials as financial managers involved in the budget preparation process consisting of Structural Officials (as Proxy of Budget Users, Commitment Making Officials, Head of Subdivision of Administration / Officials of Examiner of Order Letters. Paying, Procurement Officials) and Treasurer at the KPTIK and BMN scope of the Ministry of Finance (2) employees as financial management staff who are directly involved in budgeting at the KPTIK and BMN Ministry of Finance's work units. Furthermore, the classical assumption test was carried out and continued with the feasibility test of the model ( $F$ test) and analysis of the coefficient of determination (R2), while the MRA analysis was used for the research hypothesis test.

\section{RESULTS AND DISCUSSION}

Descriptive statistics in this study were tested to provide information about the characteristics of research variables, namely: the minimum value or the smallest or lowest value of a data set, the maximum value is the largest or highest value of a data set. The average (mean) is the most common way to measure the central value of a data distribution under study. Standard deviation is a measure that shows the standard deviation of the observed data from the average data (Ghozali, 2017).

Table 1 - Descriptive statistics

\begin{tabular}{llllll}
\hline & $\mathrm{N}$ & Min & Max & Mean & Std. Deviation \\
\hline Budget Participation (PA) & 111 & 3.17 & 6.00 & 4.9684 & .83911 \\
Organizational Commitment (KO) & 111 & 3.00 & 6.00 & 4.9275 & .89566 \\
Money Ethic (ME) & 111 & 3.00 & 5.85 & 3.8084 & .94159 \\
Organizational Ethical Culture (BE) & 111 & 3.40 & 4.60 & 3.9405 & .30582 \\
Budget Slack (SA) & 111 & 3.00 & 6.00 & 4.0090 & .82292 \\
\hline Valid N (listwise) & 111 & & & &
\end{tabular}

The data quality test used in this study was a validity test and a reliability test. The results of the validity test show that the indicators of BE1, BE2, and BE3 have a Pearson 
correlation value below 0.30 so that they must be removed from the $B E$ indicator, while for each of the other respondents' statements are greater than 0.30 so that they are suitable for use in research. While the reliability test results show that all research instruments PA, ME, $\mathrm{KO}, \mathrm{BE}$ and SA have a Cronbach's Alpha coefficient greater than 0.70 so that it can be said to be reliable and fit for use in research. This means that if the measurement is carried out more than once for the same symptom, the measurement will give consistent results.

Before performing multiple linear regression analysis, the regression model created must pass the classical assumption test first so that the resulting equation meets the BLUE (Best, Linear, Unbias, Estimator) rules so that the resulting regression model equation will have accurate predictive ability. A good regression model is a regression model in which there are no data problems with abnormal distribution, multicollinearity problems, and heteroscedasticity problems. The results of the normality test show that the coefficient value of Asymp.Sig (2-tailed) is 0.051 , greater than the alpha value of 0.05 . This shows that the study variables $\mathrm{PA}, \mathrm{ME}, \mathrm{KO}, \mathrm{BE}$, and $\mathrm{SA}$ are normally distributed. The multicollinearity test results show that all variables have a VIF value below 10 or a tolerance value above $10 \%$, so it can be stated that all variables do not have multicollinearity symptoms. While the results of the heteroscedasticity test show that all independent variables have a p-value above 0.05 , so it can be stated that there is no heteroscedasticity symptom.

Research data processing has been carried out using SPSS with the technique of moderated regression analysis / MRA and the results are as presented in Table 2.

Table 2 - Test Results of Moderated Regression Analysis (MRA)

\begin{tabular}{|c|c|c|c|c|c|c|}
\hline \multirow{2}{*}{\multicolumn{2}{|c|}{ Model }} & \multicolumn{2}{|c|}{ Unstandardized Coefficients } & \multirow{2}{*}{$\begin{array}{l}\text { Standardized Coefficients } \\
\text { Beta }\end{array}$} & \multirow[b]{2}{*}{$t$} & \multirow[b]{2}{*}{ Sig. } \\
\hline & & $\mathrm{B}$ & Std. Error & & & \\
\hline \multirow[t]{8}{*}{1} & (Constant) & 49,659 & 20,049 & & 2,477 & ,015 \\
\hline & PA & ,995 &, 672 & 1,516 & 1,480 & 044 \\
\hline & ME & 110 & 113 & 408 & 968 & , 335 \\
\hline & $\mathrm{KO}$ &,- 436 & 143 & $-1,068$ & $-3,045$ & ,003 \\
\hline & $\mathrm{BE}$ &,- 482 & 683 &,- 224 & $-2,706$ & ,028 \\
\hline & PA_ME & ,004 &, 004 & ,249 &, 994 & ,323 \\
\hline & PA_KO &,- 012 &, 005 & $-1,532$ & $-2,410$ & 018 \\
\hline & PABE &,- 084 & ,022 & $-1,460$ & $-2,248$ & ,048 \\
\hline
\end{tabular}

The results of the PA effect test on SA obtained an Unstandardized Coefficients Beta value of 0.995 with a significant value or a p-value of 0.044 which is smaller than 0.05 so it can be said that PA has a positive and significant effect on SA. Thus, the results of this test fail to reject the $\mathrm{H} 1$ hypothesis which states that budgetary participation has a significant positive effect on budgetary slack. These results support the results of previous research by Lowe and Shaw (1968), Young (1985), Lukka (1988), Falikhatun (2008), Andriyani, and Hidayati (2010), Sandrya (2013), Mahadewi (2013), Triadhi (2013). , and Maharani (2015), found that high budget participation can cause budgetary slack.

The results of the ME ability test significantly strengthened the positive effect of PA on SA, the unstandardized Coefficients Beta value of the PA_ME variable was obtained at 0.004 with a significance value or $p$-value of 0.323 which was greater than 0.05 , so it can be said that ME strengthens the insignificant effect of PA on SA. Thus, the results of this test fail to reject the $\mathrm{H} 2$ hypothesis which states that money ethics significantly strengthens the positive effect of budget participation on budgetary slack. These results are in contrast to the results of studies by Tang \& Chiu (2003) and Vitell et al (2006).

The results of the KO ability test weaken the positive effect of PA on SA, the value of Unstandardized Coefficients Beta of the PA_KO variable is -0.062 with a significance value or $p$-value of 0.018 which is smaller than 0.05 , so it can be said that KO significantly weakens the positive effect of PA on SA. Thus, the results of this test fail to reject the $\mathrm{H} 3$ hypothesis which states that organizational commitment significantly weakens the positive effect of budget participation on budgetary slack.

The results of the BE ability test significantly weaken the positive effect of PA on SA, the unstandardized Coefficients Beta value of the PA_BE variable is -0.44 with a significance 
value or $p$-value of 0.048 which is smaller than 0.05 , so it can be said that $B E$ weakens the positive effect of PA on SA. Thus, the results of this test fail to reject the $\mathrm{H} 4$ hypothesis which states that organizational commitment significantly weakens the positive effect of budget participation on budgetary slack. These results also support the results of research conducted by Marwansyah (2012: 185).

\section{CONCLUSION}

Based on the results of the analysis and discussion, it can be concluded that the results of this study are as follows:

1. Budget participation has a significant positive effect on budgetary slack in the scope of the KPTIK Satker and BMN of the Ministry of Finance or other words, the higher participation in budgeting, actually increases budgetary slack;

2. Money ethics increases but not significantly the effect of budget participation on budgetary slack in the scope of the KPTIK and BMN Ministry of Finance or other words the increase in money ethics strengthens the positive effect of budget participation on budgetary slack;

3. Organizational commitment significantly weakens the effect of positive budget participation on the budgetary slack in the scope of the KPTIK and BMN Ministry of Finance or in other words the increased organizational commitment weakens significantly the effect of budget participation on budgetary slack;

4. The ethical culture of the organization significantly weakens the positive influence of budget participation on budgetary slack or in other words, the increase in ethical culture will be able to significantly weaken the positive effect of budget participation on the budgetary slack of the KPTIK Satker and BMN of the Ministry of Finance.

\section{REFERENCES}

1. Abdullah, T. and Francis Tantri. 2012. Manajemen Pemasaran. Jakarta. PT Rajagrafindo Persada.

2. Ajzen. 2005. Attitudes, personality, and behavior. McGraw-Hill Education (UK).

3. Andriyani, Lilik., and Hidayati, L.A.2010. Pengaruh Komitmen Organisasi Terhadap Hubungan Antara Kejelasan Sasaran Anggaran and Partisipasi Anggaran Dengan Senjangan Anggaran, Studi Kasus Pada Pemerintahan Kabupaten Magelang. Universitas Muhammadyah, Malang.

4. Anthony, R.N., and V. Govindarajan. 2007. Management Control Syste. McGraw Hill.

5. Basri, Yesi Mutia. 2014. Efek Moderasi Religiusitas and Gender Terhadap Etika Uang(money ethics) and Kecurangan Pajak (TaxEvasion). Jurnal SNA 17 Mataram.Mardiasmo, 2007. Akuntansi Sektor Publik. Yogyakarta.Andi.

6. Begum, Amaliah. 2009. Pengaruh Penganggaran Partisipatif Terhadap Kesenjangan Anggaran Dengan Budaya Organisasi Sebagai Variabel Pemoderasi, Studi Kasus Pada Pemerintah Kabupaten Serang. Fakultas Ekonomi. Universitas Indonesia.

7. Brownell, P. 1982. The Role of Accounting Data in Performance Evaluation, Budgetary Partisipative, and Organizational Effectiveness. Journal of Accounting Research. Vol. 20, pp. $12-27$.

8. Chen, Y. J and Tang , T.L.P (2006), "Attitude Toward and Propensity to Engage in Unethical Behaviour: Measurement Invariance Across Major among University Students". Jurnal. Journal of Business Ethics, Vol. 69, hal: 77-93.

9. Chin-Chun, Su and Ni Feng-Yu. 2013. Budgetary Partcipation and Slack on the Theory of Planned Behavior. Internasional Journal of Organisasionalinnovation,5(3),pp:91-99.

10. Coryanata, Isma. 2007. Akuntabilitas, Partisipasi Masyarakat, and Transparansi Kebijakan Publik sebagai Pemoderating Hubungan Pengetahuan Dewan Tentang Anggaran and Pengawasan Keuangan Daerah (APBD). Simposium Nasional Akuntansi $\mathrm{X}$, Makassar. 
11. Desmiyati. 2009. Pengaruh Partisipasi Anggaran terhadap Senjangan Anggaran dengan Komitmen Organisasi sebagai Variabel Moderating. Pekbis Jurnal. Vol I, No. 2. Fakultas Ekonomi Universitas Riau.

12. Dunk, A.S. 1993. The Effect of Budget Emphasis and Information Asymmetry on the Relation Between Budgetary Participation and Slack. The Accounting Review 68. April. Pp. 300-310.

13. Elias, Z. R. \& Farag Magdy. 2010.The Relationship between Accounting Student's Love of Money and Their Ethical Perception. Managerial Editing Journal. Vol. 25, No. 3, (2010), pp. 269-281.

14. Falah, Syaikhul. 2007. Pengaruh Budaya Etis Organisasi and Orientasi Etika Terhadap Sensitivitas Etika (Studi Empiris Tentang Pemeriksaan Internal di Bawasda Pemda Papua). Tesis. Program Pascasarjana. Universitas Diponegoro. Semarang.

15. Falikhatun. 2007. Interaksi Informasi Asimetri, Budaya Organisasi and GroupCohesiveness dalam Hubungan Antara Partisipasi Penganggaran and Budgetary Slack. Symposium Nasional Akuntansi X.

16. Ghozali,Imam. 2016. Analisis Multivariate dengan SPSS. Semarang:BP UNDIP.

17. Govindarajan, V. 1986. Impact of Participation in the Budgetary Process on Managerial Attitudes and Performance: Universalistic and Contingency Perspective. Decision Science 17. Hal. 396-516.

18. Hansen, D.R., and M.M. Mowen. 1997. Management Accounting, International Editions, McGraw-Hill.

19. Hasanah, Cucu Ulvani and Suartana, Wayan. 2014. Pengaruh Interaksi Motivasi and Budaya Organisasi pada Hubungan Antara Partisipasi Penyusunan Anggaran dengan Senjangan Anggaran. E-Jurnal Akuntansi Universitas Udayana,Denpasar.

20. Hilton, Ronald W. 1994. Managerial Accounting. 2nd edition. Newyork: Mc GrawHill, Inc.

21. Ikhsan, Arfan. 2011. Akuntansi Keperilakuan. Edisi kedua. Jakarta: Salemba Empat.

22. Keller, R.T., 1997. Job Involvement and Organizational Commitment as Longitudinal Predictors of Job Performance: A Study of Scientists and Engineers. Journal of Applied Psychology. Vol. 82: 539-535.

23. Kenis, 1979. Effecton Budgetary Goal Karakteristik On Managerial Attitude and Performance. The Accounting Review. LIV(3):707-721.

24. Latuheru, Belianus Patria. 2005. Pengaruh Partisipasi Anggaran terhadap Senjangan Anggaran dengan Komitmen Organisasi sebagai Variabel Moderating. Jurnal Akuntansi \& Keuangan. Vol 7. Hal. 117-130.

25. Lukka, K. 1988. "Budgetary Biasing in Organizations: Theoritical Framework and Empirical Evidence”. Accounting, Organization, and Society 13. hal. 281-301.

26. Luthans, F. 2006. Perilaku Organisasi. Edisi Sepuluh. Yogyakarta: Penerbit Andi

27. Mahadewi,A.A. Sagung S. 2013. Pengaruh Partisipasi Penganggaran pada Senjangan Anggaran dengan Asimetri Informasi and Komitmen Organisasi sebagai Pemoderasi. EJurnal Akuntansi Universitas Udayana, 8(3), hal: 358-373.

28. Mardiasmo, 2002. Akuntansi Sektor Publik. Yogyakarta.Andi.

29. Marwansyah. 2012. Manajemen Sumber Daya Manusia. Bandung: Alfabeta.

30. Mitchell, T. R., \& Mickel. A. 1999. The meaning of money: An Individual Difference Perspective. The academy of management review, 24, 568-578.

31. Modway, R..R. Steers, and L. Porter, 1979. The Measurement of Organizational Commitment. Journal of Vacational Behavior. Vol.13, No.2: 223-235.

32. Otley, D. T. 1980. The Contingency Theory of Management Accounting: Achivement and Prognosis. Accounting, Organizational Behaviour, Heinemann: London.

33. Porter, L.W., R.M. Steers, R.T. Mowday and P.V. Boulian. 1973. Organizational Commitment, Job Satisfaction, and Turnover Among Psychiatric Technicians. Journal of Applied Psychology. Vol.59: 603-609.

34. Priliandani, Ni Made Intan. 2015. Pengaruh Partisipasi Pengangaran pada Senjangan Anggaran Di Universitas Udayanadengan Asimetri Informasi Sebagai Pemoderasi.EJurnal Akuntansi Universitas Udayana,Denpasar. 
35. Purwantini, Cornelio and Ignatius Bondan Suratno 2007. Analisis Perbedaan Sikap Wajib Pajak Orang Pribadi Terhadap Self Assessment System Pajak Penghasilan Berdasarkan Latar Belakang Wajib Pajak. Vol. 8, no. 1

36. Raudhiah, Noor, Rozita Amiruddin, and Sofiah Md Auzair. 2013. Impact of Organisational Factors On Budgetary Slack. Journal of Management and Muamalah, pp: 20-33.

37. Robbins, SP., Judge. 2002. Perilaku Organisasi, Jakarta: Salemba Empat.

38. Rubenstein, C. 1981. Money And Self-Esteem, Relationships, Secrecy, Envy, Satisfaction. Journal. Psychology Today, Vol. 15 No. 5, pp. 94-118.

Sandrya, Luh Putu and Gerianta Wirawan Yasa. 2013. Analisis Pengaruh Anggaran Partisipatif Pada Budgetary Slack Dengan Empat Variabel Moderasi (Studi kasus Pada SKPD Kabupaten Badung, Bali). E-Jurnal Akuntansi Universitas Udayana.

39. Sopiah (2008). Perilaku Organisasi, Yogyakarta: Andi Offset.

40. Sugiwardani, Resti. 2012. Analisis Pengaruh Partisipasi Anggaran, Informasi Asimetri, Budaya, and Komitmen Organisasi terhadap Budgetary Slack. Surabaya. Sekolah Tinggi Ilmu Ekonomi Perbanas.

41. Sugiyono. 2010. Metode Penelitian Kuantitatif Kualitatif \& RND. Bandung: Alfabeta.

42. Sugiyono. 2017. Statistika Untuk Penelitian. Bandung. Alfabeta.

43. Supanto. 2010. Analisis Partisipasi Penganggaran Terhadap BudgetarySlackdengan Informasi Asimetri, Motivasi, Budaya Organisasi Sebagai Pemoderasi. Universitas Diponegoro: Semarang.

44. Supriyanto. 2010. Pengaruh Partisipasi Penganggaran terhadap Budgetary Slack dengan Informasi Asimetri, Motivasi, Budaya Organisasi Sebagai Pemoderasi (Studi Kasus pada Politeknik Negeri Semarang). Universitas Diponegoro Semarang.

45. Syam, Fazli and Muslim A. Djalil. 2006. Pengaruh Orientasi Profesional Terhadap Konflik Peran: Interaksi Antara Partisipasi Anggaran and Penggunaan Anggaran Sebagai Alat Ukur Kinerja dengan Orientasi Manajerial (Suatu Penelitian Empiris Pada Perguruan Tinggi Negeri and Swasta di Provinsi Nanggroe Aceh Darussalam). Simposium Nasional Akuntansi IX, Padang.

46. Tang , T.L.P. and Chen,Y.J. 2008. Inteleligence vs Wisdom: The love of Money, Machiavellianism and Unethecial Behavior Across College Major and Gender. Journal of Business And Ethic, Vol 82, pp. 1-26.

47. Tang, T. L. P., \& Chiu, R. K. 2003. Income, Money Ethic, Pay Satisfaction, Commitment, and Unethical Behaviour: Is the Love of Money the Root of Evil for Hongkong Employees?. Journal of Business Ethics, 36, 13-30.

48. Tang, Thomas L.P. and Luna-Arocas, R 2004. The Love of Money, Satisfaction, and Protestans Work Ethic: Money Profiles Among University Prodessors in the USA and Spain. Journal of Business Ethics Volume 50, No 4: 329-354.

49. Triadi, Nyoman Andika. 2013. Pengaruh referensi, risiko, etikadan partisipasi penyusunan anggaran pada senjangan anggaran pendapatan di Pemerintah Provinsi Bali. E-Jurnal Akuntansi Universitas Udayana Bali 3(6), hal:335-355.

50. Trisnaningsih, Sri. 2007. Independensi Auditor and Komitmen Organisasi Sebagai Mediasi Pengaruh Pemahaman Good Governance, Gaya Kepemimpinan and Budaya Organisasi Terhadap Kinerja Auditor. Unhas Makassar, 26-28 Juli 2007. Universitas Pembangunan Nasional Veteran, Jawa Timur.

Vitell, S. J., Paolillo, J. G. P., \& Singh, J. J (2006). Religiosity and Consumer Ethics. Journal of Business Ethics, 57(2), 175-181.

51. Wardani Yasa, Ni Made Ayu Sri. 2016. Peran Komitmen Organisasi and Satuan Kerja Perangkat Daerah dalam Memoderasi Pengaruh Partisipasi Penganggaran pada Senjangan Anggaran. E-Jurnal Akuntansi Universitas Udayana 5(3) Hal: 905-930.

52. Young, S.M. 1985. "Participative Budgeting: The Effects of Risk Aversion and Symmetric Information on Budgeting Slack". J. of Accounting Research, Vol. 23 (2). pp. 829-832.

53. Yusfaningrum, K. and Ghozali, I. 2005. Analisis Pengaruh Partisipasi Anggaran terhadap Kinerja Manajerial melalui Komitmen Tujuann Anggaran and Job Relevant Information (JRI) sebagai Variabel Intervening (Penelitian terhadap Perusahaan Manufaktur di Indonesia). Simposium Nasional Akuntansi VIII. hal. 656-666. Solo 15-16 September. 